Subversion in Institutional Change and Stability 

Jan Olsson

\section{Subversion in}

Institutional Change and Stability

A Neglected Mechanism 
Jan Olsson

Örebro University

Örebro, Sweden

ISBN 978-1-349-94921-2

ISBN 978-1-349-94922-9 (eBook)

DOI 10.1057/978-1-349-94922-9

Library of Congress Control Number: 2016946834

(C) The Editor(s) (if applicable) and The Author(s) 2016

The author(s) has/have asserted their right(s) to be identified as the author(s) of this work in accordance with the Copyright, Designs and Patents Act 1988.

This work is subject to copyright. All rights are solely and exclusively licensed by the Publisher, whether the whole or part of the material is concerned, specifically the rights of translation, reprinting, reuse of illustrations, recitation, broadcasting, reproduction on microfilms or in any other physical way, and transmission or information storage and retrieval, electronic adaptation, computer software, or by similar or dissimilar methodology now known or hereafter developed.

The use of general descriptive names, registered names, trademarks, service marks, etc. in this publication does not imply, even in the absence of a specific statement, that such names are exempt from the relevant protective laws and regulations and therefore free for general use. The publisher, the authors and the editors are safe to assume that the advice and information in this book are believed to be true and accurate at the date of publication. Neither the publisher nor the authors or the editors give a warranty, express or implied, with respect to the material contained herein or for any errors or omissions that may have been made.

Printed on acid-free paper

This Palgrave Macmillan imprint is published by Springer Nature The registered company is Macmillan Publishers Ltd. London 
FOR

Gittan,

Jonathan, and Oliver 



\section{ACKNOWLEDgments}

This book was developed from a conference paper entitled 'Politics as Institutional Subversion: a neglected mechanism in explaining institutional change and continuity'. It was presented at the International Conference on Public Policy in Milan, Italy, 1-4 July 2015. Theme 10, Panel 12: Political Agency in the Policy Process. The idea of making a short book, a so-called Pivot, was suggested at the conference by the Commissioning Editor Jemima Warren at Palgrave Macmillan. I immediately liked the idea of developing my arguments on subversive action and institutional dynamics at greater length than a conference paper or an article could afford. I am really grateful to Jemima for this good idea and for our efficient cooperation during quite an intensive autumn!

There are a number of other persons who have supported me with comments in the process of theorizing and writing. A draft of the conference paper was presented at the Political Science Seminar at Örebro University, Sweden. My colleague Joachim Åström was a discussant at this seminar and contributed with critical comments that were really valuable for making the final version of the conference paper. I am also grateful for comments and ideas from a number of colleagues at the seminar: Renée Andersson, Cecilia Arensmeier, Viktor Dahl, Gun Hedlund, Erik Hysing, Ann-Catrin Kristianssen, and Mats Lindberg.

At the Milan conference I had the opportunity to present the paper and receive comments. I want to particularly thank the two discussants for important comments and a nice discussion: Petra Svensson (School of Public Administration) and Magdalena Zeijlon (Global Studies), both from Gothenburg University, Sweden. I am also grateful for comments 
from other panel participants: Stijn Brouwer, KWR Watercycle Research Institute, the Netherlands, and Sina Leipold, University of Freiburg, Germany.

My dear colleague and intellectual partner Erik Hysing has read most of the manuscript at different stages of the process. His constructive comments have been really important and helpful, as always, and I look forward to our future cooperation. Of course, as the author I bear full responsibility for any remaining shortcomings of this book and I hope to be able to further develop some of the arguments in future texts.

Last but not least, there are no words to express all that I owe to my near and dear ones: Gittan, Jonathan, and Oliver. Thanks for our intensive discussions, your honesty, and patient love! 


\section{Contents}

1 Introduction 1

Stability, Change, and Political Agency 1

Structure and Content of the Book 5

$\begin{array}{ll}\text { References } & 7\end{array}$

2 Agency in New Institutionalism 11

A Critical Assessment of Micro-Level Theorizing in new
Institutionalism

A Third Phase of Theorizing? $\quad 20$

Taking Political Agency Seriously $\quad 26$

References $\quad 32$

3 Subversive Action $\quad 39$

The Nature and Meaning of the Concept 39

Subversive Action in the Literature 44

Summary and Conclusions $\quad 57$

Note $\quad 58$

References $\quad 58$

4 Subversive Action in Context 63

A Few Words on Context 63

The General Argument $\quad 64$

Subversive Acts on Different Levels of Organization $\quad 70$ 
$\mathrm{x}$ CONTENTS

Subversive Action and Value Conflicts $\quad 77$

References $\quad 79$

5 Stability, Change, and Subversive Action 83

Institutional Stability and Change 83

Stability through Subversive Action $\quad 84$

Institutional Change through Subversive Action 87

Theorizing on Strategies and Tactics of Subversive Action 92

References 101

6 Conclusions and Reflections 105

Main Arguments and Findings $\quad 105$

Some Ethical Aspects on Subversive Action 107

Future Research Needs 109

References 113

$\begin{array}{ll}\text { References } & 115\end{array}$

$\begin{array}{ll}\text { Index } & 117\end{array}$ 